\title{
Vegetation changes following brush control in creosotebush communities
}

\author{
HOWARD L. MORTON AND ALICIA MELGOZA
}

\begin{abstract}
Changes in herbaceous plant density and canopy cover of creosotebush (Larrea tridentata Sesse \& Moc. ex DC) and associated shrubs following brush control treatments were measured in Sonoran and Chihuahuan Desert communities. Treatments were applied in 2 successive years at the Santa Rita Experimental range, Arizona, and 3 locations in Chihuahua, Mexico. Across all locations and years $1.5 \mathrm{~kg} / \mathrm{ha}$ tebuthiuron $(N-5$-(1,1-dimethylethyl)1,3,4-thiadiazol-2-yl\}- $N, N^{\prime}$-dimethylurea\} $>1.0 \mathrm{~kg} / \mathrm{ha}$ tebuthiuron $=$ disking $=$ disking with furrowing $>2$-way railing $>0.5 \mathrm{~kg} / \mathrm{ha}$ tebuthiuron $>$ land imprinting in reducing canopy cover of creosotebush and associated shrubs. At the Santa Rita Experimental Range annual precipitation was above long-term mean in 1982, 1983, 1984, and 1985; and grass density increased on all treated and untreated plots. Annual precipitation was below long-term mean during 1986 and 1987 and grass density decreased on both treated and untreated plots but did not decrease to pre-treatment densities. Forb densities were less than 3 plants $/ \mathrm{m}^{2}$ throughout the study, except in 1987 when Russian thistle (Salsola iberica Sennen \& Pau) increased on all plots. At the Chihuahuan locations, grass densities usually increased during the first year of the study, but very low precipitation throughout the study caused subsequent reductions in grass and forb densities. In dry years brush control treatments did not increase herbaceous plant density.
\end{abstract}

Key Words: Larrea tridentata, disking, land imprinting, Sonoran Desert, Chihuahuan Desert, railing, grass density, shrub cover, tebuthiuron

\footnotetext{
Authors are plant physiologist, USDA-ARS, Aridland Watershed Management Research Unit, 2000 E. Allen Road, Tucson, Ariz. 85719; and biologist, Rancho Experimental "La Campana," INIFAP, SARH, Apartado Postal 682, Chihuahua, Chih., Mexico 31000 . When this study was initiated, Melgoza was a graduate student, School of Renewable Natural Resources, University of Arizona, Tucson.

Appreciation is expressed to DowElanco for the herbicide and fencing materials used at the sites in Mexico; personnel of Rancho Experimental La Campana, Chihuahua and Aridland Rangeland Management Research Research Unit, Tucson, for assistance in conducting the research; Eloy Morales, Sergio Mendoza, and Gilberto Valdez for permission to use their land and housing facilities; and the Rocky Mountain Forest and Range Experiment Station for permission to use land on the Santa Rita Experimental Range.

Manuscript accepted May 29, 1990.
}

Creosotebush (Larrea tridentata Sesse \& Moc. ex DC) covers about $262,680 \mathrm{~km}^{2}$ in the United States (Kuchler 1964) and about $453,250 \mathrm{~km}^{2}$ in Mexico (Leopold 1950). According to Gardner (1951) creosotebush increased in both countries from 1910 to 1950 , and continues to increase in density and area (Buffington and Herbel 1965, Herbel et al. 1985). As creosotebush and associated woody species increase, forage production decreases (Anderson et al. 1957). Likewise, when woody plant populations are removed or thinned, forage production increases (Morton et al. 1978, Scifres et al. 1979, Jacoby et al. 1982, Herbel et al. 1983). Traditionally, creosotebush has been controlled by mechanical methods: disking, root plowing, roller chopping, shredding, and railing. Disking and root plowing uproot woody plants and are most effective on shallow rooted plants such as big sagebrush (Artemisia tridentata Nutt.) and creosotebush (Holechek et al. 1989), but they also destroy most herbaceous plants. Railing, shredding, chaining, land imprinting, and roller chopping remove the tops of plants, but usually kill fewer woody plants than disking or root plowing.

Chemical methods have been developed for creosotebush control with tebuthiuron $\{N$-[5-(1,1-dimethylethyl)-1,3,4-thiadiazol-2yl]- $N, N^{\prime}$-dimethylurea\} perhaps the most effective. It controls creosotebush and many other woody species on rangelands (Morton et al. 1978, Herbel et al. 1985).

The objectives of this study were to measure changes in herbaceous plant density and canopy cover of creosotebush and associated shrubs in Sonoran and Chihuahuan Desert communities after broadcast applications of tebuthiuron at $0.5,1.0$, and $1.5 \mathrm{~kg}$ a.i. $/ \mathrm{ha}$ rates, land imprinting, 2-way railing, disking, and disking with furrowing. Tebuthiuron was applied at 3 rates because results of previous research on creosotebush suggested that control varied with soil depth and texture, and grass and forb responses varied with rate (Jacoby et al. 1982, Herbel et al. 1985).

Disking was included as a standard for comparison with other methods. Disking with furrowing was added to determine if this treatment would aid in water conservation and increase the density of herbaceous plants. Railing and land imprinting were included because they have relatively low energy requirements. Land 
Table 1. Monthly and total annual precipitation at Santa Rita Experimental Range from 1981 to 1987 and 11-year monthly mean.

\begin{tabular}{|c|c|c|c|c|c|c|c|c|}
\hline \multirow[b]{2}{*}{ Month } & \multicolumn{7}{|c|}{ Year } & \multirow{2}{*}{$\begin{array}{c}11 \text {-year }^{1} \\
\text { monthly mean }\end{array}$} \\
\hline & 1981 & 1982 & 1983 & 1984 & 1985 & 1986 & 1987 & \\
\hline January & 0 & 44 & 11 & 49 & $\underset{39}{(\mathrm{~mm})}$ & 0 & 25 & 18 \\
\hline February & 0 & 31 & 88 & 0 & 90 & 29 & 2 & 31 \\
\hline March & 28 & 36 & 70 & 0 & 26 & 25 & 11 & 21 \\
\hline April & 2 & 0 & 0 & 12 & 0 & 4 & 21 & 4 \\
\hline May & 0 & 7 & 10 & 4 & 12 & 24 & 29 & 9 \\
\hline June & 5 & 10 & 0 & 0 & 0 & 26 & 2 & 5 \\
\hline July & 79 & 143 & 102 & 130 & 22 & 22 & 11 & 63 \\
\hline August & 9 & 118 & 168 & 184 & 127 & 105 & 65 & 86 \\
\hline September & 29 & 58 & 66 & 59 & 48 & 26 & 23 & 38 \\
\hline October & 5 & 0 & 191 & 98 & 79 & 0 & 6 & 36 \\
\hline November & 0 & 26 & 0 & 0 & 38 & 10 & 17 & 13 \\
\hline December & - 19 & 55 & 65 & 78 & 24 & 56 & 50 & 35 \\
\hline Total & 176 & 528 & 771 & 614 & 505 & 327 & 262 & 359 \\
\hline
\end{tabular}

'Precipitation from 1977 to 1987.

imprinting is a relatively new method and must be compared with other methods before it can be recommended on rangelands.

\section{Materials and Methods}

The study was conducted on the Santa Rita Experimental Range (SRER), $40 \mathrm{~km}$ south of Tucson, Ariz., in the Sonoran Desert and at 3 locations in the Chihuahuan Desert of Mexico: Ranchos El Toro, $100 \mathrm{~km}$ east of Villa Ahumada; La Reforma, $60 \mathrm{~km}$ east of Parral; and Los Pozos, $20 \mathrm{~km}$ northeast of Aldama. Elevation is $970 \mathrm{~m}$ at SRER, $1,500 \mathrm{~m}$ at $\mathrm{La}$ Reforma, and about $1,400 \mathrm{~m}$ at Los Pozos and El Toro. Long-term mean annual precipitation at SRER, La Reforma, Los Pozos, and El Toro' ${ }^{1}$ is $359,428,328$, and $227 \mathrm{~mm}$, respectively. At the Chihuahuan locations 70 to $90 \%$ of the annual precipitation occurs June through September (SARH 1982) but is bimodal at SRER, with about $60 \%$ occurring June through October and $40 \%$ in fall, winter, and spring (Green and Martin 1967). The uneven distribution of precipitation is natural, as is the drought which occurs at most Sonoran and Chihuahuan locations each year during late spring and early summer. Less severe drought in early winter occurs in the Sonoran Desert. The spring drought is usually broken in July and the winter drought by precipitation in December or January (Table 1). Because precipitation in the Chihuahuan Desert occurs primarily in summer months, plants usually undergo stress during early summer before rains begin in June or July (SARH 1982). Rainfall during the study

Ing. Sergio Mendoz provided 15-year precipitation records from Rancho El Toro and 3 adjacent ranches from which precipitation monthly and annual means were calculated rather than from the 22 -year record from Villa Ahumada $100 \mathrm{~km}$ to the west. was measured by individual rain gauges maintained within the study sites at each location.

Slope inclination varies from 2 to $16 \%$ at La Reforma, and from 0 to $5 \%$ at the other 3 locations. Surface soil textures at the 4 sites are sandy loams underlain by a caliche hardpan that ranges from 5 to $100 \mathrm{~cm}$ below the soil surface. Physical and chemical properties, soil series, and classification are shown in Table 2 (Soil Survey Staff 1975).

Creosotebush was the dominant shrub at all locations except $\mathrm{La}$ Reforma, where it shared dominance with whitethorn acacia ( $A \mathrm{Ca}$ cia constricta Benth), shrubby senna (Cassia wislizeni Gray), and tarbush (Flourencia cernua DC.). Mariola (Parthenium incanum H.B.K.), whitethorn acacia, and tarbush were abundant at Los Pozos; javelina brush (Condalia eriocoides [A. Gray] M.C. Johnston), and honey mesquite (Prosopis glandulosa Torr.) et El Toro; and velvet mesquite ( $P$. velutina Woot.) and desert zinnia (Zinnia pumila Gray) at SRER. The most abundant native grasses were fluffgrass (Erioneuron pulchellum [H.B.K.] Tateoka) at all locations; black grama (Bouteloua eriopoda Torr.) at La Reforma and El Toro; threeawns (Aristida spp.) at Los Pozos and SRER; bushmuhly (Muhlenbergia porterii Scribn.) at Los Pozos, El Toro; and SRER; spike pappusgrass (Enneapogon Desvauxii Beauv.) at Los Pozos, and sideoats grama (B. curtipendula [Michx.] Torr.) at La Reforma.

Study areas (about $30 \mathrm{ha}$ ) at all locations were fenced to exclude livestock in summer 1981 and divided into 2 parts: 1 for treatment in 1981 and 1 for treatment in 1982. Each part was subdivided into 24 plots, 50 by $100 \mathrm{~m}$. The experimental design was a randomized block with 3 replications. The following 8 treatments were applied: broadcast applications of $20 \%$ pellets of tebuthiuron at (1) $0.5,(2)$ 1.0 , and (3) $1.5 \mathrm{~kg} \mathrm{a.i./} \mathrm{ha,} \mathrm{(4)} \mathrm{land} \mathrm{imprinting,} \mathrm{(5)} \mathrm{2-way} \mathrm{railing,} \mathrm{(6)}$ disk plowing, (7) disk plowing with contour furrowing, and (8) untreated check.

Hand application of the tebuthiuron pellets was accomplished by crisscrossing plots 4 times: twice lengthwise using 10 swaths each $5 \mathrm{~m}$ wide and twice crosswise on 20 swaths, each $5 \mathrm{~m}$ wide. The clay pellets contained $20 \%$ a.i. tebuthiuron and were $3.2 \mathrm{~mm}$ in diameter and approximately $4.8 \mathrm{~mm}$ in length.

The rail consisted of three $2.65-\mathrm{m}$ lengths of railroad steel bolted together to form a triangle and weighted with rock (approximately $770 \mathrm{~kg}$ ). The rail was pulled over the plot twice in opposite directions. A standard 3-bottom disk plow on a 3-point hitch weighing $500 \mathrm{~kg}$ was used at the Mexican sites, and a pull-type 3-bottom disk plow weighing, $1,000 \mathrm{~kg}$ was used at the SRER. Both disk plows had $65-\mathrm{cm}$ diameter disks which penetrated soils to $30 \mathrm{~cm}$. A border disk constructed contour furrows at $10-\mathrm{m}$ intervals.

The land imprinter, fabricated from $1.27-\mathrm{cm}$ thick steel plate, consisted of 2 non-directional geometric forms (V-pitter and pitdigger) welded on separate $1-$ by $1-m$ cylindrical capsules. Capsules

Table 2. Physical and chemical properties, series, and classification of the upper $20 \mathrm{~cm}$ of soils at Ranchos La Reforma, Los Pozos, and, El Toro, Chihuahua, Mexico, and at Santa Rita Experimental Range (SRER), Arizona, United States of America.

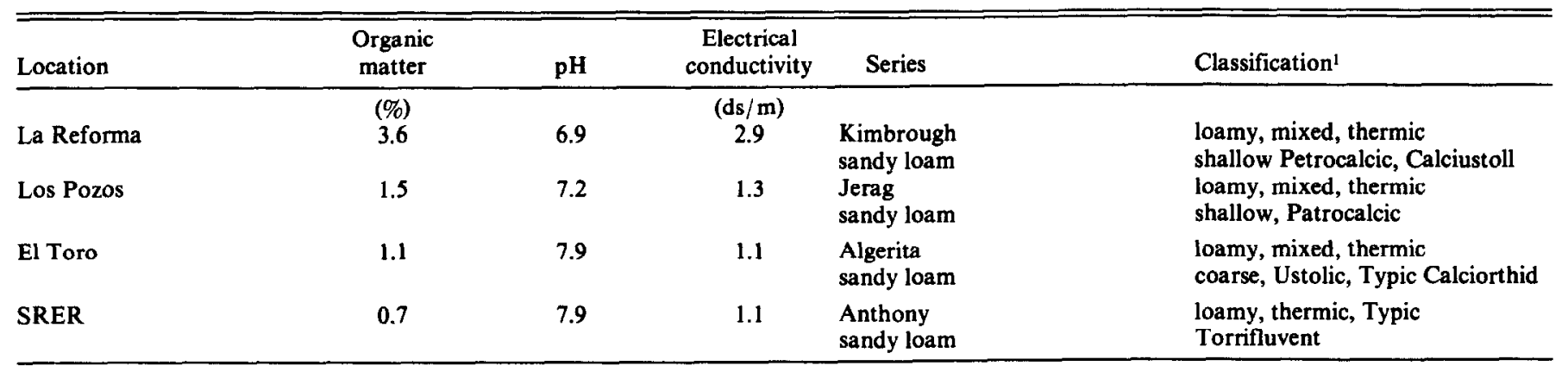

'Soil classification is from Soil Survey Staff (1975). 
Table 3. Density (plants $/ \mathrm{m}^{2}$ ) of grasses and forbs measured before treatment in 1981 or 1982 with 3 tebuthiuron rates and 4 mechanical control methods and remeasured in 1984, 1986, or 1987 at SRER.

\begin{tabular}{|c|c|c|c|c|c|c|c|c|c|c|c|c|}
\hline \multirow[b]{3}{*}{ Treatment } & \multicolumn{6}{|c|}{1981 Treatments } & \multicolumn{6}{|c|}{1982 Treatments } \\
\hline & \multicolumn{3}{|c|}{ Grasses } & \multicolumn{3}{|c|}{ Forbs } & \multicolumn{3}{|c|}{ Grasses } & \multicolumn{3}{|c|}{ Forbs } \\
\hline & $\begin{array}{l}\text { May } \\
1981\end{array}$ & $\begin{array}{l}\text { Oct } \\
1984\end{array}$ & $\begin{array}{l}\text { Oct } \\
1986\end{array}$ & $\begin{array}{l}\text { May } \\
1981\end{array}$ & $\begin{array}{l}\text { Oct } \\
1984\end{array}$ & $\begin{array}{l}\text { Oct } \\
1986\end{array}$ & $\begin{array}{l}\text { May } \\
1982\end{array}$ & $\begin{array}{l}\text { Oct } \\
1984\end{array}$ & $\begin{array}{l}\text { Oct } \\
1987\end{array}$ & $\begin{array}{l}\text { May } \\
1982\end{array}$ & $\begin{array}{l}\text { Oct } \\
1984\end{array}$ & $\begin{array}{l}\text { Oct } \\
1987\end{array}$ \\
\hline & & & & & & -. & $\left.1^{2}\right) \cdots$ & 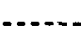 & $\ldots$ &.- & -. & $\ldots$ \\
\hline $\begin{array}{l}\text { Tebuthiuron, } 0.5 \\
\mathrm{~kg} / \mathrm{ha}\end{array}$ & 1 & 8 & 5 & 1 & $\mathbf{T}^{\mathbf{1}}$ & $\mathrm{T}$ & 0 & 12 & 8 & 3 & 1 & 8 \\
\hline $\begin{array}{l}\text { Tebuthiuron, } 1.0 \\
\mathrm{~kg} / \mathrm{ha}\end{array}$ & 1 & 10 & 8 & 2 & $\mathbf{T}$ & $T$ & 2 & 2 & 4 & $\mathbf{T}$ & $\mathbf{T}$ & 21 \\
\hline $\begin{array}{l}\text { Tebuthiuron, } 1.5 \\
\text { kg/ha }\end{array}$ & 2 & 10 & 6 & 1 & $\mathrm{~T}$ & $\mathbf{T}$ & 2 & 8 & 6 & 2 & $T$ & 8 \\
\hline Land imprinting & $T$ & 5 & 3 & 2 & 2 & 1 & 1 & 20 & 4 & 1 & 2 & 36 \\
\hline 2-way railing & 3 & 13 & 10 & 1 & 3 & 2 & 2 & 18 & 12 & 3 & 2 & 16 \\
\hline Disking & 2 & 4 & 5 & 4 & 3 & 3 & 2 & 7 & 5 & 4 & 1 & 48 \\
\hline $\begin{array}{l}\text { Disking with } \\
\text { furrowing }\end{array}$ & 2 & 4 & 5 & 1 & 3 & 4 & 1 & 23 & 8 & 4 & 1 & 14 \\
\hline Untreated check & 3 & 6 & 4 & 1 & 4 & 1. & 2 & 13 & 5 & 5 & 1 & 12 \\
\hline Date average & 2 & 8 & 6 & 2 & 2 & 1 & 2 & 13 & 8 & 3 & 1 & 20 \\
\hline L.S.D. 0.05 & NS $^{2}$ & 7 & NS & NS & 2 & NS & NS & 10 & 5 & NS & NS & NS \\
\hline
\end{tabular}

TT = Less than 0.5 plants $/ \mathrm{m}^{2}$

${ }^{2} \mathrm{NS}=$ No significant difference at the $5 \%$ level of probability.

were filled with water and linked on a shaft. Iron boxes located at the front and rear were filled with rock to aid in soil penetration (Dixon and Simanton 1980). Total weight was approximately 4 metric tons.

Mechanical treatments were applied between 14 June and 17 July 1981 and between 26 May and 27 June 1982. Land imprinter treatments were applied at SRER only in 1981 and at all sites in 1982. Tebuthiuron was applied in May of both years.

Prior to treatment, 3 permanent line transects $30 \mathrm{~m}$ long were established in each plot. Shrub canopy cover was determined by measuring the canopy that intercepted the transect, and from those values percent canopy cover was calculated. Herbaceous plant density was determined by counting grasses and forbs on belts $\mathbf{3 0}$ $\mathrm{cm}$ wide on the $30-\mathrm{m}$ transect. Measurements were made before treatment at all locations in May 1981 and 1982. SRER plots treated in 1981 were remeasured in October 1984 and October 1986, and plots treated in May 1982 were remeasured in October 1984 and October 1987. At La Reforma, Los Pozos, and El Toro, plots treated in 1981 were remeasured in May 1982, May 1983, and September 1983, and plots treated in 1982 were remeasured in May and September 1983. Because vegetation changes were very small at the Chihuahuan locations subsequent to the first year following May treatment, only data from the initial May measurements and the May 1983 remeasurements are shown.

Herbaceous density and shrub cover data were subjected to analyses of variance and, where appropriate, mean separation was performed using the protected LSD mean separation technique to compare cover and density on treated plots with the cover and density on untreated check plots at a location within the year of treatment (Steel and Torrie 1980).

\section{Results and Discussion}

\section{Santa Rita Experimental Range \\ Precipitation}

Annual precipitation in 1981 was below long-term mean, but July precipitation was above average (Table 1). In 1982, 1983, 1984, and 1985 annual precipitation was above the long-term mean, but in 1986 and 1987 precipitation was below the long-term mean. In 1985 and 1986 the spring drought was not broken until August. Precipitation was above average in September, October, and November 1985, but was far below average in September, October, and November 1986. During 1987 precipitation was

Table 4. Cover (\%) of creosotebush and other shrubs measured before treatment in 1981 or 1982 with 3 tebuthiuron rates and 4 mechanical control methods and remeasurement in 1986 or 1987 at SRER.

\begin{tabular}{|c|c|c|c|c|c|c|c|c|}
\hline \multirow[b]{3}{*}{ Treatment } & \multicolumn{4}{|c|}{1981 Treatments } & \multicolumn{4}{|c|}{1982 Treatments } \\
\hline & \multicolumn{2}{|c|}{ Creosotebush } & \multicolumn{2}{|c|}{ Other Shrubs } & \multicolumn{2}{|c|}{ Creosotebush } & \multicolumn{2}{|c|}{ Other Shrubs } \\
\hline & $\begin{array}{l}\text { May } \\
1981\end{array}$ & $\begin{array}{c}\text { Oct } \\
1986\end{array}$ & $\begin{array}{l}\text { May } \\
1981\end{array}$ & $\begin{array}{c}\text { Oct } \\
1986\end{array}$ & $\begin{array}{l}\text { May } \\
1982\end{array}$ & $\begin{array}{c}\text { Oct } \\
1987 \\
\end{array}$ & $\begin{array}{l}\text { May } \\
1982\end{array}$ & $\begin{array}{c}\text { Oct } \\
1987\end{array}$ \\
\hline & $-\cdots$ & & & - & 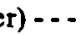 & & & $--\cdot$ \\
\hline Tebuthiuron, $0.5 \mathrm{~kg} / \mathrm{ha}$ & 25 & 3 & 1 & 1 & 28 & 9 & 8 & 3 \\
\hline Tebuthiuron, $1.0 \mathrm{~kg} / \mathrm{ha}$ & 22 & $T^{1}$ & 7 & 2 & 22 & $\mathbf{T}$ & 8 & 1 \\
\hline Tebuthiuron, $1.5 \mathrm{~kg} / \mathrm{ha}$ & 22 & 0 & 3 & 1 & 24 & $\mathbf{T}$ & 10 & 2 \\
\hline Land imprinting & 25 & 12 & 3 & 3 & 21 & 11 & 11 & 6 \\
\hline 2-way railing & 35 & 10 & 5 & 4 & 20 & 5 & 5 & 6 \\
\hline Disking & 18 & 6 & 2 & 4 & 25 & 2 & 8 & 3 \\
\hline Disking with furrowing & 18 & 2 & 4 & 4 & 30 & 4 & 4 & 4 \\
\hline Untreated check & 26 & 18 & 5 & 7 & 23 & 17 & 5 & 6 \\
\hline Date average & 24 & 6 & 4 & 3 & 24 & 6 & 7 & 4 \\
\hline L.S.D. 0.05 & 12 & 8 & $\mathbf{N S}^{2}$ & 3 & 8 & 10 & NS & NS \\
\hline
\end{tabular}

I $\mathrm{T}=$ Less than $0.5 \%$ cover

${ }^{2} \mathrm{NS}=$ No significant difference at the $5 \%$ level of probability 


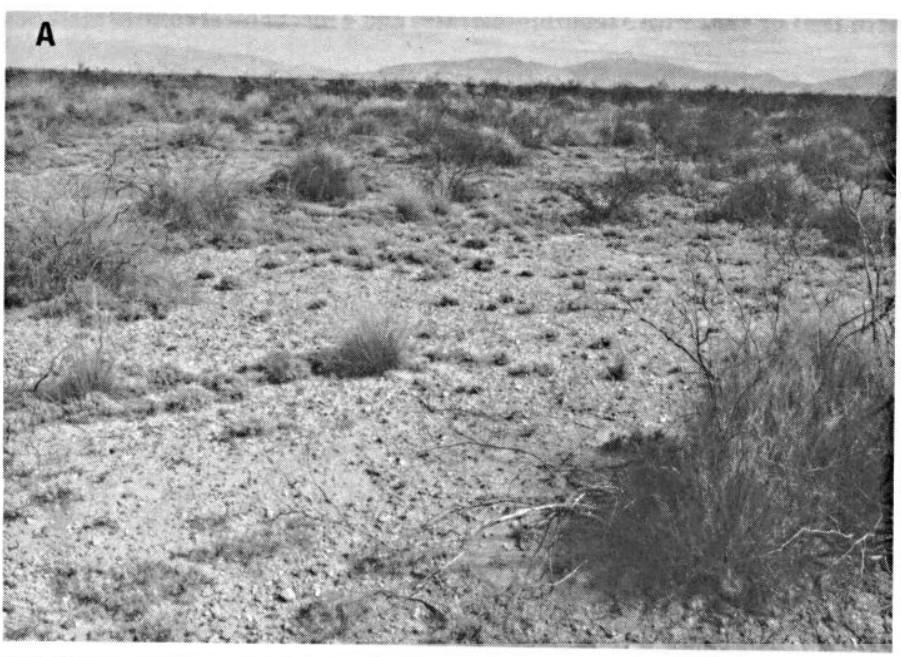

B

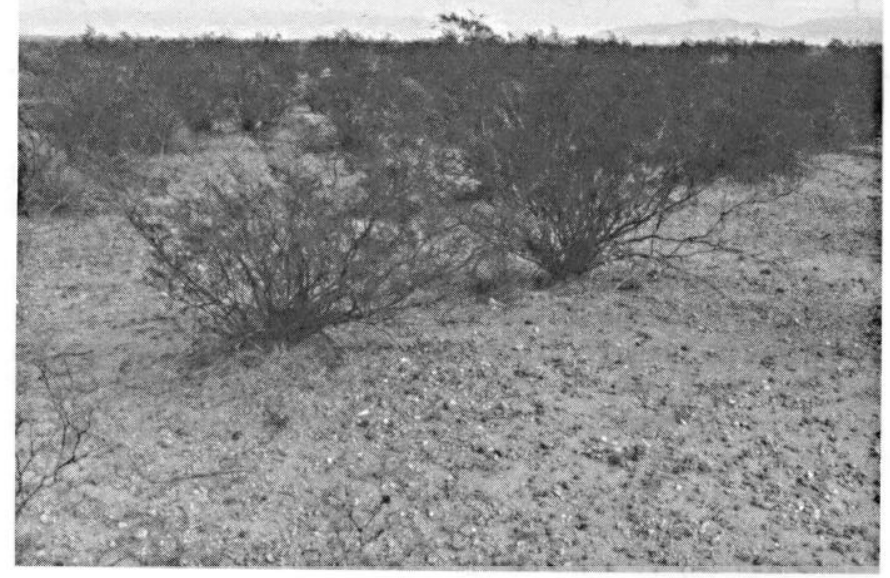

Fig. 1. Tebuthiuron plot treated at $0.5 \mathrm{~kg}$ a.i./ha in May 1981 at Santa Rita Experimental Range (A) and untreated check plot (B): both photographed October 1984.

below long-term mean throughout the summer and fall.

\section{Grass Density}

Perennial grass density averaged about 2.0 plants $/ \mathrm{m}^{2}$ prior to brush control on both the 1981 and 1982 plots (Table 3). After above-average summer rainfall in 1982, 1983, and 1984, grass densities increased on nearly all plots but there were few differences among treatments when remeasurements were made in October 1984 , 1986, or 1987. Fluffgrass and threeawn made up most of the density changes. Bushmulhy plants increased in size on the tebuthiuron plots but density remained about the same (Figs. 1A and 1B). Increased growth of bushmuhly may be related to the higher fertility levels of soil under the dead creosotebush plants, as documented by Cox et al. (1983). The increase in size of bushmuhly was not observed on the land imprinted and 2-way railed plots because these mechanical methods did not kill the shrub plants (Fig. 2). Disking and disking with furrowing killed most of the bushmuly plants. Spike dropseed (Sporoblus contractus Hitchc.) was abundant on the disked and disked with furrowing plots in 1984, 1986, and 1987 but not when treatments were applied (Fig. 3).

The data in Table 3 do not indicate that tebuthiuron lowered grass densities, and they do not show any significant increase in grass density due to water retention by furrows or depressions

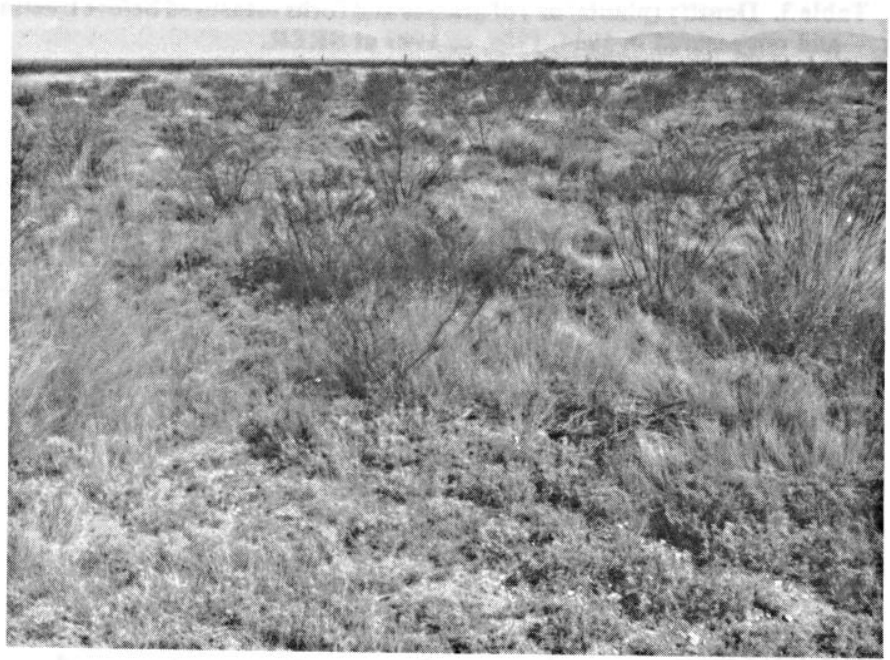

Fig. 2. Two-way railed plot treated June 1982 at Santa Rita Experimental Range and photographed October 1984. Note creosotebush regrowth and abundance of fluffgrass and threeawn plants.

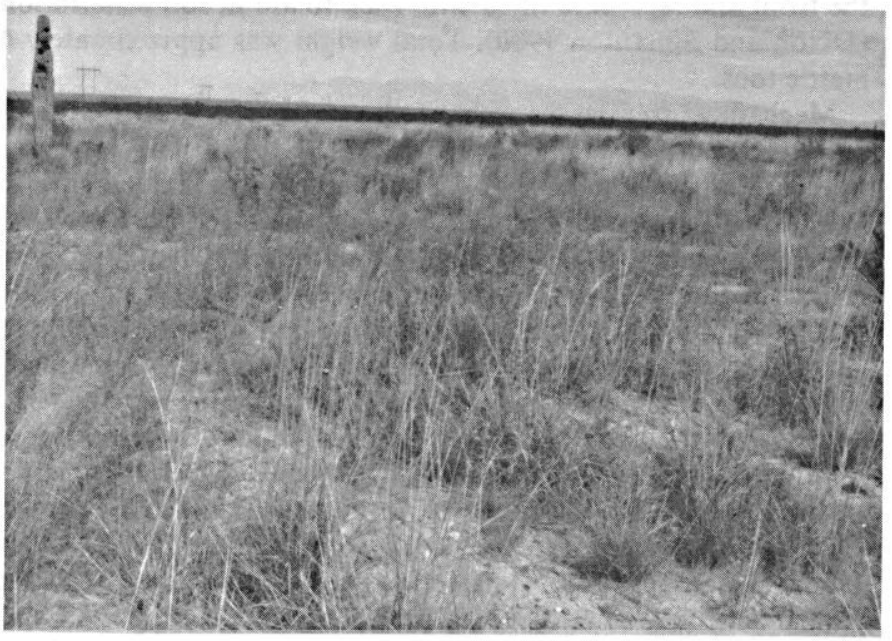

Fig. 3. Disk plowed plot treated June 1982 at Santa Rita Experimental Range and photographed October 1984 . Tall grass plants are primarily spike dropseed and short grass plants are threeawns.

created by the border disk or land imprinter. Grass densities were highest and significantly different from the checks on 2-way railed plots. The rail is an implement which tends to smooth rather than increase surface roughness.

\section{Forb Density}

Winter forbs were present on all plots before treatment in 1981 and 1982 (Table 3), but density varied within and between plots and averaged 2 and 3 plants/ $\mathrm{m}^{2}$ in May 1981 and 1982, respectively. Forb density remained about the same between the time of treatment in 1981 or 1982 and remeasurement in 1984. The plants measured in October 1984 were primarily summer annuals but densities of winter forbs measured in the spring of 1983 (data not shown) did not differ significantly from densities in the fall, even though the species were different. Forb density was essentially unchanged between 1984 and 1986 on plots treated in 1981, but 
Table 5. Precipitation ( $\mathrm{mm}$ ) at 3 Chihuahuan locations in 1981, 1982, and 1983.

\begin{tabular}{lccc}
\hline \hline Months/Years & La Reforma & Los Pozos & El Toro \\
\hline$\ldots \ldots \ldots \ldots \ldots \ldots \ldots$ & 148 & 141 & 198 \\
June-September 1981 & 58 & 121 & 28 \\
October-May 1981-82 & 38 & 73 & 188 \\
June-September 1982 & 28 & 10 & 25 \\
October-May 1982-83 & 104 & 93 & 135 \\
June-September 1983 & & & \\
Long-term Mean & 365 & 268 & 171 \\
June-September & 63 & 60 & 56 \\
October-May & & & \\
\hline
\end{tabular}

there was a dramatic increase in forb density between 1984 and 1987 on plots treated in 1982. Russian thistle (Salsola ibirica Sennen \& Pau) accounted for much of the increase. Russian thistle germinated and became established on all tebuthiuron and mechanically treated plots. Johnsen and Morton (1989) found that 5 years after a $0.9 \mathrm{~kg} / \mathrm{ha}$ application $5 \%$ of the applied tebuthiuron remained in a semiarid soil of northcentral Arizona. They found averages of 21,88 , and $127 \mathrm{~g} /$ ha remaining in the $0-$ to $7-, 7-$ to $15-$, and $15-$ to $30-\mathrm{cm}$ depths, respectively, after 5 years. Tebuthiuron was found in soil treated at 2 or more $\mathrm{kg}$ / ha 11 years after application. This information suggests Russian thistle is tolerant of low amounts of tebuthiuron. Russian thistle establishment apparently was aided by the mechanical treatments as well as the environmental conditions in 1987. While increases in Russian thistle occurred on the untreated check plots of the 1982 treatments, Russian thistle density increases were not detected in 1986 on the 1981 treatments.

Table 6. Density of grasses and forbs (plants $/ \mathrm{m}^{2}$ ) measured before treatment in 1981 or 1982 with 3 tebuthiuron rates and 4 mechanleal methods and remeasured in 1983 at Rancho La Reforma, Chihuahua.

\begin{tabular}{|c|c|c|c|c|c|c|c|c|}
\hline \multirow[b]{3}{*}{ Treatment } & \multicolumn{4}{|c|}{ Grasses } & \multicolumn{4}{|c|}{ Forbs } \\
\hline & \multicolumn{2}{|c|}{1981 Treatment } & \multicolumn{2}{|c|}{1982 Treatment } & \multicolumn{2}{|c|}{1981 Treatment } & \multicolumn{2}{|c|}{1982 Treatment } \\
\hline & $\begin{array}{l}\text { May } \\
1981\end{array}$ & $\begin{array}{l}\text { May } \\
1983\end{array}$ & $\begin{array}{l}\text { May } \\
1982\end{array}$ & $\begin{array}{l}\text { May } \\
1983\end{array}$ & $\begin{array}{l}\text { May } \\
1981\end{array}$ & $\begin{array}{l}\text { May } \\
1983\end{array}$ & $\begin{array}{l}\text { May } \\
1982\end{array}$ & $\begin{array}{l}\text { May } \\
1983\end{array}$ \\
\hline & & & 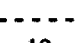 & $\cdots(1$ & $-\cdots$ & $\cdots$ & -- & --- \\
\hline Tebuthiuron, $0.5 \mathrm{~kg} / \mathrm{ha}$ & 3 & 2 & 19 & 1 & 48 & $T^{\prime}$ & 2 & 0 \\
\hline Tebuthiuron, $1.0 \mathrm{~kg} / \mathrm{ha}$ & 1 & 1 & 20 & 1 & 44 & $\mathbf{T}$ & 2 & 0 \\
\hline Tebuthiuron, $1.5 \mathrm{~kg} / \mathrm{ha}$ & $\mathrm{T}$ & 1 & 24 & 1 & 82 & $\mathrm{~T}$ & $\mathbf{T}$ & 0 \\
\hline Disking & 6 & $\mathbf{T}$ & 16 & 1 & 83 & $\mathrm{~T}$ & $\mathbf{T}$ & $\mathbf{T}$ \\
\hline Disking with furrowing & 1 & $\mathbf{T}$ & 28 & 1 & 85 & $T$ & 1 & 3 \\
\hline Untreated check & $\mathrm{T}$ & $\mathrm{T}$ & 29 & 2 & 78 & $\mathrm{~T}$ & 3 & 2 \\
\hline Date average & 2 & 1 & 22 & 2 & 69 & $T$ & 2 & 1 \\
\hline L.S.D. 0.05 & $\mathbf{N S}^{4}$ & NS & NS & N̦S & NS & NS & NS & NS \\
\hline
\end{tabular}

IT = Less than 0.5 plants $/ \mathrm{m}^{2}$

${ }^{2}$ Land imprinting treatments were not applied in 1981 at Chihuahuan locations 3 - No data

$4 \mathrm{NS}=$ No significant difference at the $5 \%$ level of probability

Table 7. Density of grasses and forbs (plants/ $\mathrm{m}^{2}$ ) measured before treatment in 1981 or 1982 with 3 tebuthiuron rates and 4 mechanical methods and remeasured in 1983 at Rancho Los Pozos, Chihuahua.

\begin{tabular}{|c|c|c|c|c|c|c|c|c|}
\hline \multirow[b]{3}{*}{ Treatment } & \multicolumn{4}{|c|}{ Grasses } & \multicolumn{4}{|c|}{ Forbs } \\
\hline & \multicolumn{2}{|c|}{1981 Treatment } & \multicolumn{2}{|c|}{1982 Treatment } & \multicolumn{2}{|c|}{1981 Treatment } & \multicolumn{2}{|c|}{1982 Treatment } \\
\hline & $\begin{array}{l}\text { May } \\
1981\end{array}$ & $\begin{array}{l}\text { May } \\
1983\end{array}$ & $\begin{array}{l}\text { May } \\
1982\end{array}$ & $\begin{array}{l}\text { May } \\
1983\end{array}$ & $\begin{array}{l}\text { May } \\
1981\end{array}$ & $\begin{array}{l}\text { May } \\
1983\end{array}$ & $\begin{array}{l}\text { May } \\
1982\end{array}$ & $\begin{array}{l}\text { May } \\
1983\end{array}$ \\
\hline & $\ldots$ & $\ldots$ & $\ldots$ & $\ldots($ & )- & $\ldots$ & $\ldots$ & $\ldots$ \\
\hline Tebuthiuron, $0.5 \mathrm{~kg} / \mathrm{ha}$ & 26 & 9 & 9 & 13 & 18 & 20 & 31 & 14 \\
\hline Tebuthiuron, $1.0 \mathrm{~kg} / \mathrm{ha}$ & 38 & 7 & 13 & 11 & 34 & 19 & 34 & 9 \\
\hline Tebuthiuron, $1.5 \mathrm{~kg} / \mathrm{ha}$ & 9 & 9 & 11 & 13 & 21 & 11 & 31 & 18 \\
\hline Land imprinting & -2 & _- & 9 & 11 & - & - & 28 & 31 \\
\hline 2-way railing & 19 & 7 & 8 & 10 & 75 & 28 & 32 & 59 \\
\hline Disking & 8 & 2 & 9 & 3 & 68 & 36 & 25 & 36 \\
\hline Disking with furrowing & 5 & 3 & 7 & 4 & 48 & 34 & 34 & 29 \\
\hline Untreated check & 33 & 9 & 7 & 11 & 33 & 42 & 34 & 28 \\
\hline Date average & 20 & 7 & 9 & 10 & 42 & 28 & 31 & 28 \\
\hline L.S.D. 0.05 & $\mathrm{NS}^{3}$ & NS & NS & 3 & NS & 17 & NS & 21 \\
\hline
\end{tabular}

'Land imprinting treatments were not applied in 1981 at Chihuahuan locations 2 - No data

NNS $=$ No significant difference at the $5 \%$ level of probability 
Table 8. Density of grasses and forbs (plants/ $\mathrm{m}^{2}$ ) measured before treatment in 1981 or 1982 with 3 tebuthiuron rates and 4 mechanlcal methods and remeasured in 1983 at Rancho $\mathrm{El}$ Toro, Chihuahua.

\begin{tabular}{|c|c|c|c|c|c|c|c|c|}
\hline \multirow[b]{3}{*}{ Treatment } & \multicolumn{4}{|c|}{ Grasses } & \multicolumn{4}{|c|}{ Forbs } \\
\hline & \multicolumn{2}{|c|}{1981 Treatment } & \multicolumn{2}{|c|}{1982 Treatment } & \multicolumn{2}{|c|}{1981 Treatment } & \multicolumn{2}{|c|}{1982 Treatment } \\
\hline & $\begin{array}{l}\text { May } \\
1981\end{array}$ & $\begin{array}{l}\text { May } \\
1983\end{array}$ & $\begin{array}{l}\text { May } \\
1982\end{array}$ & $\begin{array}{l}\text { May } \\
1983\end{array}$ & $\begin{array}{l}\text { May } \\
1981\end{array}$ & $\begin{array}{l}\text { May } \\
1983\end{array}$ & $\begin{array}{l}\text { May } \\
1982\end{array}$ & $\begin{array}{c}\text { May } \\
1983\end{array}$ \\
\hline & $\ldots$ & $\ldots$ & $\ldots$ & $---(1$ & --- & $\ldots$ & $-\ldots$ & -- \\
\hline Tebuthiuron, $0.5 \mathrm{~kg} / \mathrm{ha}$ & 4 & 7 & 17 & 8 & 49 & 5 & 3 & 4 \\
\hline Tebuthiuron, $1.0 \mathrm{~kg} / \mathrm{ha}$ & 6 & 7 & 16 & 9 & 58 & 4 & 3 & 3 \\
\hline Tebuthiuron, $1.5 \mathrm{~kg} / \mathrm{ha}$ & 6 & 4 & 16 & 8 & 69 & 3 & 1 & 3 \\
\hline Land imprinting 1 & -2 & - & $\longrightarrow$ & 9 & $\ldots$ & - & - & 6 \\
\hline 2-way railing & 7 & 12 & - & 1 & 63 & 14 & - & 6 \\
\hline Disking & 4 & 4 & - & $\mathrm{T}^{3}$ & 66 & 11 & - & 5 \\
\hline Disking with furrowing & 5 & 6 & - & $\mathrm{T}$ & 48 & 11 & - & 2 \\
\hline Untreated check & 6 & 15 & 14 & 18 & 49 & 5 & 4 & 1 \\
\hline Date average & 5 & 8 & 16 & 6 & 56 & 8 & 2 & 4 \\
\hline L.S.D. 0.05 & 4 & 6 & $\mathbf{N S}^{4}$ & 7 & NS & 4 & NS & 3 \\
\hline
\end{tabular}

'Land imprinting treatments were not applied in 1981 at Chihuahuan locations

${ }^{2}-=$ No dats

${ }^{3} \mathrm{~T}=$ Less than 0.5 plants $/ \mathrm{m}^{2}$

$4 \mathrm{NS}=$ No significant difference at the $5 \%$ level of probability

Table 9 Canopy cover of shrubs (\%) measured before treatment in 1981 or 1982 with 3 tebuthiuron rates and 4 mechanical methods and remeasured in 1983 at Ranchos La Reforma, Los Pozos, and El Toro, Chihuahua.

\begin{tabular}{|c|c|c|c|c|c|c|c|c|c|c|c|c|}
\hline \multirow[b]{3}{*}{ Treatment } & \multicolumn{4}{|c|}{ La Reforma } & \multicolumn{4}{|c|}{ Los Pozos } & \multicolumn{4}{|c|}{ El Toro } \\
\hline & \multicolumn{2}{|c|}{1981 Treatment } & \multicolumn{2}{|c|}{1982 Treatment } & \multicolumn{2}{|c|}{1981 Treatment } & \multicolumn{2}{|c|}{1982 Treatment } & \multicolumn{2}{|c|}{1981 Treatment } & \multicolumn{2}{|c|}{1982 Treatment } \\
\hline & $\begin{array}{l}\text { May } \\
1981\end{array}$ & $\begin{array}{l}\text { May } \\
1983\end{array}$ & $\begin{array}{l}\text { May } \\
1982\end{array}$ & $\begin{array}{l}\text { May } \\
1983\end{array}$ & $\begin{array}{l}\text { May } \\
1981\end{array}$ & $\begin{array}{l}\text { May } \\
1983\end{array}$ & $\begin{array}{c}\text { May } \\
1982\end{array}$ & $\begin{array}{l}\text { May } \\
1983\end{array}$ & $\begin{array}{l}\text { May } \\
1981\end{array}$ & $\begin{array}{l}\text { May } \\
1983\end{array}$ & $\begin{array}{c}\text { May } \\
1982\end{array}$ & $\begin{array}{l}\text { May } \\
1983\end{array}$ \\
\hline $\begin{array}{l}\text { Tebuthiuron, } 0.5 \mathrm{~kg} / \mathrm{ha} \\
\text { Tebuthiuron, } 1.0 \mathrm{~kg} / \mathrm{ha} \\
\text { Tebuthiuron, } 1.5 \mathrm{~kg} / \mathrm{ha} \\
\text { Land imprinting } \\
\text { 2-way railing } \\
\text { Disking } \\
\text { Disking with furrowing } \\
\text { Untreated check }\end{array}$ & $\begin{array}{l}35 \\
42 \\
32 \\
-3 \\
28 \\
36 \\
26 \\
28\end{array}$ & $\begin{array}{r}7 \\
10 \\
1 \\
- \\
5 \\
4 \\
5 \\
29\end{array}$ & $\begin{array}{l}37 \\
32 \\
34 \\
30 \\
37 \\
38 \\
35 \\
38\end{array}$ & $\begin{array}{r}-- \\
12 \\
8 \\
7 \\
5 \\
2 \\
4 \\
6 \\
21\end{array}$ & $\begin{array}{l}-2 \\
19 \\
20 \\
14 \\
- \\
21 \\
18 \\
13 \\
19\end{array}$ & $\begin{array}{c}-1 \% \\
6 \\
4 \\
2 \\
- \\
5 \\
3 \\
3 \\
21\end{array}$ & $\begin{array}{c}\text { er) -- } \\
19 \\
20 \\
22 \\
-- \\
-- \\
-- \\
-- \\
20\end{array}$ & $\begin{array}{r}-- \\
10 \\
5 \\
1 \\
5 \\
2 \\
2 \\
2 \\
17\end{array}$ & $\begin{array}{l}18 \\
15 \\
19 \\
\overline{14} \\
16 \\
11 \\
11\end{array}$ & $\begin{array}{c}2 \\
1 \\
\mathrm{~T}^{\prime} \\
2 \\
1 \\
1 \\
13\end{array}$ & $\begin{array}{l}-- \\
19 \\
28 \\
22 \\
- \\
- \\
- \\
-\end{array}$ & $\begin{array}{r}-2 \\
4 \\
4 \\
2 \\
4 \\
2 \\
1 \\
1 \\
18\end{array}$ \\
\hline Date average & 32 & 9 & 35 & 8 & 18 & 7 & 20 & 6 & 15 & 3 & 20 & 4 \\
\hline L.S.D. 0.05 & $\mathbf{N S}^{4}$ & 13 & $\mathbf{N S}$ & 4 & 10 & 11 & NS & 10 & 9 & 4 & NS & 8 \\
\hline
\end{tabular}

$\mathrm{IT}=$ Less than $0.5 \%$ cover

'Land imprinting treatments were not applied in 1981 at Chihuahuan locations

$3-=$ No data

$4 \mathrm{NS}=$ No significant difference at the $5 \%$ level of probability

\section{Creosotebush and Other Shrub Cover}

Creosotebush canopy cover was lower 6 growing seasons after treatment compared to untreated check except on plots where land imprinting and 2-way railing were applied in 1981 and where land imprinting and tebuthiuron at $0.5 \mathrm{~kg} / \mathrm{ha}$ were applied in 1982 (Table 4). Tebuthiuron at 1.0 and $1.5 \mathrm{~kg} / \mathrm{ha}$, disking, and disking with furrowing reduced creosotebush canopy cover by about $21 \%$.

All treatments reduced cover of other shrubs when plots were remeasured in 1982 (data not shown); but cover, due to regrowth on land imprinted and 2-way railed plots, was equal to or near pre-treatment levels in 1986 (Table 4). Land imprinting was not effective in reducing desert zinnia cover from 1981 to 1986 when applied to wet soil but did in 1982 when soil was dry (data not shown). Between 1984 and remeasurements in 1986 or 1987, cover of other shrubs did not change or increased only slightly.

\section{Chihuahuan Desert Locations}

\section{Precipitation}

June to September precipitation was below the Iong-term mean at La Reforma and Los Pozos throughout the study (Table 5). In
1981 summer precipitation was only about $50 \%$ of the long-term mean at both locations but it was evenly distributed throughout the growing season. Summer precipitation during 1982 was very low at both locations. The only significant rainfall at La Reforma in 1983 was $80 \mathrm{~mm}$ in August. At Los Pozos, October to May 1981-1982 precipitation was about twice the long-term mean, but the June to September precipitation in 1982 and 1983 was far below the longterm mean. At El Toro the June to September precipitation was slightly above long-term mean in 1981 and 1982 but October to May precipitation was about half the long-term mean each year.

\section{Grass and Forb Density}

At La Reforma grass density before treatment in May in 1981 and May 1982 averaged 2 and 22 plants $/ \mathrm{m}^{2}$, respectively (Table 6). Sideoats grama, black grama, and fluffgrass were the most abundant species. The higher density in May 1982 was probably due to grazing exclusion during the previous year and the relatively even distribution of precipitation during the 1981 June to September period, which permitted the establishment of perennial grass seedlings. Grass density decreased on all treated and untreated plots 
from May 1982 to May 1983 during a period of very low precipitation. All grass species on all treatments were adversely affected by low precipitation in 1982 and 1983. Cool-season forb density before treatment in May 1981 averaged 69 plants $/ \mathrm{m}^{2}$ and included 37 different species. By May 1982 forb density had dropped dramatically on both treated and untreated plots. Below-average precipitation continued during 1982 and 1983 and forb densities were low until the study was terminated in October 1983.

At Los Pozos grass density before treatments were applied averaged 20 and 9 plants $/ \mathrm{m}^{2}$ on the 1981 and 1982 treatments, respectively (Table 7). Grass density usually decreased on the 1981 treatments between 1981 and 1983. There were slight increases on the 19820.5 and $1.5 \mathrm{~kg} /$ ha tebuthiuron, land imprinted, 2-way railed, and check plots, but decreases occurred on the disked and disked with furrowed plots. Forb density decreased on all the 1981 treatments except the $0.5 \mathrm{~kg} /$ ha tebuthiuron and decreased on all the 1982 treatments except the land imprinted, 2-way railed, and disked plots.

At El Toro black grama was the most abundant grass species; however, saltgrass (Distichlis stricta [Torr.] Rydb.), fluffgrass, and bushmuly were also numerous on most of the plots (Table 8). Slight increases occurred in the density of grasses on most of the 1981 plots. Decreases occurred in the density of grasses on the 1982 tebuthiuron plots due to toxicity of tebuthiuron to black grama. A slight increase in density occurred on the untreated check. Forbs were abundant before brush control treatments were applied in May 1981, but their density decreased on all treated and untreated plots during the study. The decrease was probably due to the very low precipitation during the October to May periods of 1981-1982 and 1982-1983, which would have prevented establishment and growth of winter annual forbs (Table 5).

\section{Creosotebush and Other Shrub Cover}

Creosotebush canopy cover at the time of treatment averaged $3 \%$ on the 1981 and 1982 plots at La Reforma, but other shrubs averaged 29 and $32 \%$ on the 1981 and 1982 plots, respectively. Thus, total shrub cover was higher at La Reforma than at the other 2 Chihuahuan locations and the SRER (Tables 4 and 9). All tebuthiuron and mechanical treatments applied in both years at the Chihuahuan locations reduced shrub cover except the $0.5 \mathrm{~kg} / \mathrm{ha}$ tebuthiuron treatment in 1982 at Los Pozos. There were small changes in shrub canopy cover on the untreated check plots during the study. The decreases were usually associated with low precipitation. Increases were mostly associated with growth of individual plants.

\section{Conclusions}

Over all locations and years, the treatments reduced shrub canopy cover in the following order: $1.5 \mathrm{~kg} / \mathrm{ha}$ tebuthiuron $>1.0$ $\mathbf{k g} /$ ha tebuthiuron $=$ disking $=$ disking with furrowing $>$ 2-way railing $>0.5 \mathrm{~kg} /$ ha tebuthiuron $>$ land imprinting. During the 6-growing-season study in the Sonoran Desert community, grass density increased in all treatments when precipitation was above normal, but density decreased when precipitation was below average. However, grass densities remained above their pre-treatment levels on all treatments. In cont rast, forb densities did not increase except in 1987, the second year of below-average precipitation, and then the increase was due primarily to Russian thistle. Because of very low precipitation at the Chihuahuan locations, grass and forb densities decreased below pre-treatment levels after an initial 1year increase.

Furrowing and land imprinting are treatments designed to increase amounts of water retained in the soil (Anderson et al. 1957, Dixon and Simanton 1980). In arid areas furrowing and land imprinting should reduce runoff and retain water for use by plants on the treated site. At SRER grass densities on plots receiving disking with furrowing were not greater than on plots disked only. Grass densities were highest and significantly different from the checks on 2-way railed plots. The rail is an implement which tends to smooth rather than increase surface roughness. Data from this study suggest that furrowing and land imprinting are not effective in increasing grass or forb densities in a Sonoran Desert creosotebush community. When precipitation was below average, brush control treatments did not increase herbaceous plant density.

\section{Literature Cited}

Anderson, D., L.P. Hamilton, H.G. Reynolds, and R.R. Humphrey. 1957. Reseeding desert grassland ranges in southern Arizona. (Revised) Arizona Agr. Exp. Sta. Bull. 249.

Buffington, L.C., and C.H. Herbel. 1965. Vegetation changes on a semidesert grassland range. Ecol. Monogr. 35:139-164.

Cox, J.R., H.A. Schreiber, and H.L. Morton. 1983. The initial growth of two range grasses on nonfertilized and fertilized soils collected from creosotebush communities in the Southwestern United States. J. Range Manage. 36:726-729.

Dixon, R.M., and J.R. Simanton. 1980. Land imprinting for better water management: Symposium on watershed management. Vol. II. Amer. Soc. Civil Eng. p. 809-825, Boise, Ida.

Gardner, J.L. 1951. Vegetation of the creosotebush area of the Rio Grande Valley in New Mexico. Ecol. Mono. 21:379-403.

Green, C.R., and S.C. Martin. 1967. An evaluation of precipitation, vegetation and related factors on the Santa Rita Experimental Range. Univ. of Arizona, Institute of Atmospheric Physics. Tech. Report on Meteorology and Climatology of Arid Regions. No. 17.

Herbel, C.W., W.L. Gould, W.F. Leifeste, and R.P. Gibbens. 1983. Herbicide treatment and vegetation response to treatment of mesquite in southern New Mexico. J. Range Manage. 36:149-151.

Herbel, C.H., H.L. Morton, and R.P. Gibbens. 1985. Controlling shrubs in the arid Southwest with tebuthiuron. J. Range Manage. 38:391-394.

Holechek, J.L., R.D. Pieper, and C.H. Herbel. 1989. Range management principles and practices. Prentice-Hall, Inc., Englewood Cliffs, N.J.

Jacoby, P.W., D.N. Ueckert, and F.S. Hartman. 1982. Control of creosotebush (Larrea tridentata) with pelleted tebuthiuron. Weed Sci. 30:307-310.

Johnsen, T.N., Jr., and H.L. Morton. 1989. Tebuthiuron persistence and distribution in some semiarid soils. J. Envir. Qual. 18:433-438.

Kuchler, A.W. 1964. Potential natural vegetation of the conterminous United States. Amer. Geo. Soc. Spec. Pub. 36.

Leopold, A.S. 1950. Vegetation zones of Mexico. Ecology 31:507-518.

Morton, H.L., E.L. Smith, M. Oliveira, and H.M. Hull. 1978. Soil applied herbicides for brush control in Southwestern United States and Northeast Brazil, p. 647-650. In: Proc. 1st Int. Rangeland Congress (ed. D.N. Hyder), Soc. Range Manage. Denver, Colo.

SARH. 1982. Direccion General del Servicio Meteorologico Nacional Nornal Climatologicas. Periodo/1941-1970. Mexico, D.F. [Spanish]

Scifres, C.J., J.L. Mutz, and W.T. Hamilton. 1979. Control of mixed brush with tebuthiuron. J. Range Manage. 32:155-158.

Soil Survey Staff. 1975. Soil taxonomy: A basic system of soil classification for making and interpreting soil surveys. USDA-SCS Agr. Handb. 436. U.S. Gov. Printing Office, Washington, D.C.

Steel, R.G.D., and J.H. Torrie. 1980. Principles and procedures of statistics-a biometrical approach. McGraw Hill, New York. 